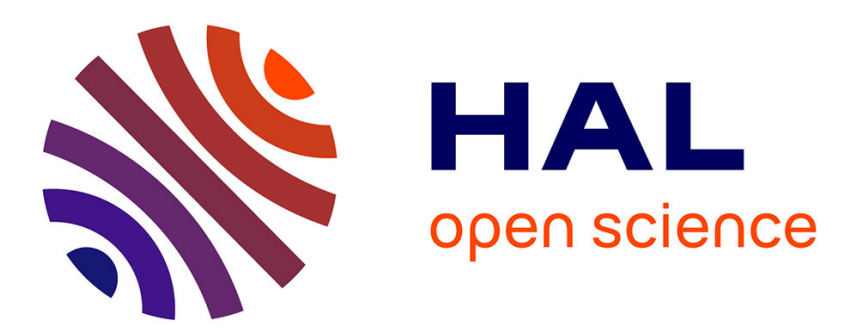

\title{
Assessment of Penicillium expansum and Escherichia coli transfer from poplar crates to apples
}

Mathilde Montibus, Rached Ismail, Valérie Michel, Michel M. Federighi, Florence Aviat, Isabelle Le Bayon

\section{- To cite this version:}

Mathilde Montibus, Rached Ismail, Valérie Michel, Michel M. Federighi, Florence Aviat, et al.. Assessment of Penicillium expansum and Escherichia coli transfer from poplar crates to apples. Food Control, 2016, 60, pp.95-102. 10.1016/j.foodcont.2015.07.025 . hal-02637131

\section{HAL Id: hal-02637131 https://hal.inrae.fr/hal-02637131}

Submitted on 27 May 2020

HAL is a multi-disciplinary open access archive for the deposit and dissemination of scientific research documents, whether they are published or not. The documents may come from teaching and research institutions in France or abroad, or from public or private research centers.
L'archive ouverte pluridisciplinaire HAL, est destinée au dépôt et à la diffusion de documents scientifiques de niveau recherche, publiés ou non, émanant des établissements d'enseignement et de recherche français ou étrangers, des laboratoires publics ou privés. 


\title{
Assessment of Penicillium expansum and Escherichia coli transfer from poplar crates to apples
}

\author{
Mathilde Montibus ${ }^{\text {a, }}{ }^{\text {, }}$, Rached Ismaïl b, c, Valerie Michel ${ }^{\text {d }}$, Michel Federighi ${ }^{\text {b, c }}$, \\ Florence Aviat ${ }^{\mathrm{b}, \mathrm{c}}$, Isabelle Le Bayon ${ }^{\mathrm{a}}$ \\ a Institut technologique FCBA, Allée de Boutaut, BP 227, 33028 Bordeaux cedex, France \\ ${ }^{\mathrm{b}}$ LUNAM, Oniris, SECALIM, Route de Gachet, CS 40706, 44307 Nantes, France \\ ' INRA, UMR1014, SECALIM, 44307 Nantes, France \\ d ACTALIA Produits Laitiers, 419 Route des Champs Laitiers, CS 50030, 74801 La Roche sur Foron, France
}

\section{A R T I C L E I N F O}

\section{Article history:}

Received 26 April 2015

Received in revised form

16 July 2015

Accepted 17 July 2015

Available online 18 July 2015

\section{Keywords:}

Wooden surfaces

Transfer

Apples

Microorganisms

Contamination

\begin{abstract}
A B S T R A C T
Poplar crates are widely used in contact with foodstuffs. One of the major markets for poplar crates is apple packaging. As a direct food contact material, wood is subject to European regulation $\mathrm{n}^{\circ} 1935 / 2004$, which requires no negative effect of material or packaging on foodstuffs. This study aims to quantify the transfer of Penicillium expansum conidia and Escherichia coli from poplar specimens to Golden apples. This [microorganisms-poplar-Golden apple] model was developed taking into account realistic parameters with extreme and usual conditions. Poplar specimens were artificially contaminated with $P$. expansum and E. coli. They were then put in contact with apples and stored in a climatic room for up to one week. Both wood specimens and apples were analyzed to assess the survival of microorganisms on wood specimens and the proportion of microorganism transfer to apples. Whereas P. expansum conidia survived but did not grow on wood specimens, E. coli mortality was observed after one hour of contact with wood. The proportion of both microorganisms transferred to apples was less than $0.25 \%$. The impact of wood moisture content, contact time between wood and apples, and apple supply variability on the transfer levels were studied. The hygroscopic properties of wood were discussed. The low and reproducible transfer levels observed demonstrate that poplar is a safe packaging material for apples.
\end{abstract}

(c) 2015 Elsevier Ltd. All rights reserved.

\section{Introduction}

As a traditional and natural material, wood is widely used in the food industry and in home kitchens. Wooden utensils, packaging and working surfaces, such as cutting boards and ripening shelves, are used for their "technological", mechanical or hygroscopic properties. Thus, some hardwood and softwood species, like oak, cherry tree and spruce, are considered as "technological tools". They contribute to the organoleptic qualities of wine (Gougeon et al., 2009), vinegars (Callejón, Torijab, Masb, Moralesa, \& Troncosoa, 2010) and cheese ripening due to their hygroscopic and microbiological properties (Mariani et al., 2011; Richard, 1997).

\footnotetext{
* Corresponding author.

E-mail addresses: mathilde.montibus@fcba.fr (M. Montibus), rached.ismail@ oniris-nantes.fr (R. Ismaïl), v.michel@actalia.eu (V. Michel), michel.federighi@ oniris-nantes.fr (M. Federighi), florence.aviat@oniris-nantes.fr (F. Aviat), isabelle. lebayon@fcba.fr (I. Le Bayon).
}

Moreover, Filip et al. carried out microbiological analysis by swabbing 105 samples of wooden trays (Abies spp.) and 105 of plastic trays (PET) used for drying fresh pasta (Filip, Fink, Oder, \& Jevšnik, 2012). The authors showed that the total number of microorganisms ( $\mathrm{CFU} / 20 \mathrm{~cm}^{2}$ ) was significantly lower on wooden frames compared to plastic frames and that $30 \%$ of swabs sampled from plastic frames exceeded $200 \mathrm{CFU} / 20 \mathrm{~cm}^{2}$, whereas the value for wooden frames was only $3 \%$. Secondly, Escherichia coli was not detected among the 210 samples, Staphylococcus aureus was significantly lower on wooden (3\% positive swabs) than on plastic frames (54\% positive swabs). The levels of moulds and yeasts were significantly lower on wooden frames compared to plastic frames. With these results the authors concluded that wood is appropriate in the food industry from a hygienic and technological point of view.

Because of their lightness, their mechanical resistance to shocks and their high tolerance to moisture, hardwood and sapwood species are chosen by manufacturers. They are selected to make 
crates, boxes and pallets for packaging foodstuffs (such as fruits, vegetables, fish, shellfish and cheeses). In France, more than 20 wood species are authorized by the French ministerial order of November 1945 (Anonymous, 1945) and the information note of the Economy and Finance French Ministry (Anonymous, 2012) for use in direct contact with solid or liquid food products.

In France, fruit and vegetables is the main food sector using wooden packaging, generally made from poplar, maritime pine, scots pine, spruce and douglas pine. Poplar is particularly common for manufacturing light packaging such as crates intended for fruits and vegetables.

As a direct food contact material, wood can be subject to specific regulations. For example, in Europe, regulation ECR 1935/2004 (1935/2004, 2004) specifies that materials intended for safe food contact must not modify foodstuff characteristics.

In order to check the ability of surfaces to be in direct contact with food, microbiological tools are needed. Analyses of packaging material can be used as quality control procedures thus preventing the contamination of foods (Kusumaningrum, Riboldi, Hazeleger, \& Beumer, 2003) by cross-contamination events. In fact, food contact surfaces have been shown to be responsible for such crosscontamination (Sanborn, 1963). Other studies have described the survival of Listeria monocytogenes (S. A. Wilks, Michels, \& Keevil, 2006) and E. coli 0157 (S. Wilks, Michels, \& Keevil, 2005) on stainless steel surfaces. In 2011, Pui et al. reported the transfer of Salmonella spp. from plastic surfaces to dragon fruits (Pui et al., 2011). However, studies on wooden packaging are lacking.

The aim of this study was to assess the microbiological transfer from wooden packaging to food in an accurate "food-wood" contact model. For this purpose, we studied and quantified transfer levels from inoculated poplar crates, as contact surfaces, to Golden apples. We chose two relevant hygienic risk models. Firstly, Penicillium expansum, is an important spoilage Eurotiomycetes in the fruit sector, particularly for apples and pears (Amiri, Cholodowski, \& Bompeix, 2005). The mold P. expansum is known to be responsible for one of the major postharvest decay of apples called blue mold (Conway et al., 2004; Ikeura, Somsak, Kobayashi, Kanlayanarat, \& Hayata, 2011; Xiao, Kim, \& Boal, 2014) and of several fresh fruits like tomatoes (Chatterton, Wylie, \& Punja, 2012), peaches (Liu, Jiang, Bi, \& Luo, 2005; Yu et al., 2012), winter pear (Sanderson \& Spotts, 1995), jujube fruits (Cao, Li, Tian, \& Qin, 2012; Liting Wang, Wu, Qin, \& Meng, 2014), date palm fruits (Palou, Montesinos-Herrero, Taberner, \& Vilella-Esplá, 2013) and sweet cherries (Lei Wang et al., 2015). Secondly, E. coli, a gram-negative bacterium, is often used as an indicator of general hygienic practices in the food industry. coli $157: \mathrm{H} 7$ was found to be responsible for causing diarrhea in people having ingested freshly-pressed apple cider (Richard, 1997). Several studies have demonstrated that E. coli, and mostly serotype 0157:H7, can colonize apple surfaces after aqueous contamination (Buchanan, Edelson, Miller, \& Sapers, 1999) or when contaminated water is used in washing or processing fruits (Vojdani, Beuchat, \& Tauxe, 2008). Many scientific studies have demonstrated that $E$. coli can survive and/or grow in several minimally processed fruits, such as peaches (Alegre, Abadias, Anguera, Usall, \& Viñas, 2010), pineapples (Sivapalasingam, Friedman, Cohen, \& Tauxe, 2004), honeydew melons (Leverentz, Conway, Janisiewicz, \& Camp, 2004), apples (Alegre et al., 2010; Janisiewicz, Conway, \& Leverentz, 1999) and bruised apples (Dingman, 2000).

To study the microorganism transfer from wood to apples, we used a new method that was developed to quantify microorganisms in the wood matrix (Ismaïl et al., 2014). The influence of different parameters was explored by their impact on the transfer rate of $P$. expansum spores and non-pathogenic $E$. coli. Different contact times between inoculated poplar samples and apples were tested. Different wood moisture contents were compared.

\section{Materials and methods}

The [microorganisms-poplar-Golden apple] model was developed taking into account realistic parameters of the use of packaging crates for Golden apples. The usual conditions and duration of storage were used for this model. An "extreme scenario" was considered by selecting a high level of microorganism inoculation on wood, a high level of wood moisture content (37\%) to increase the survival of microorganisms, and a long time of contact between wood and apples to obtain optimal conditions for the transfer of microorganisms to apples.

\subsection{Wood specimens and apples}

Populus $x$ euramericana (I214 clone) poplar sapwood strips were freshly rotary cut to a thickness of $0.4 \mathrm{~cm}$ (Bois Diffusion, Valanjou, France). Wood specimens measuring $60 \times 40 \mathrm{~mm}$ (corresponding to a surface area of $24 \mathrm{~cm}^{2}$ ) were cut from these strips. After 14 days of conditioning in a climatic chamber at $20{ }^{\circ} \mathrm{C} \pm 2{ }^{\circ} \mathrm{C}$ and $65 \% \pm 5 \%$ relative humidity $(\mathrm{RH})$, wood specimens were packed in sealed bags and sterilized by ionizing radiation (Gamma rays, $25 \mathrm{kGy}$ ) prior to use (Ionisos, Dagneux, France).

Golden Delicious apples from two French suppliers were used in this study. They were stored at $4{ }^{\circ} \mathrm{C} \pm 2{ }^{\circ} \mathrm{C}$ and disinfected with $70 \%$ ethanol prior to use. As a control, contact plates of PCA medium (tryptone $5 \mathrm{~g} / \mathrm{L}$, yeast extract $2.5 \mathrm{~g} / \mathrm{L}$, glucose $1 \mathrm{~g} / \mathrm{L}$ ) were applied for $10 \mathrm{~s}$ to the surface of apples and incubated at $22^{\circ} \mathrm{C} \pm 2{ }^{\circ} \mathrm{C}$ for $48 \mathrm{~h}$ to ensure that disinfection had been fully carried out.

\subsection{Determination of contact surface area between wood specimens and apples}

Apples (Golden, diameter 70) were stained in a black painting bath for $30 \mathrm{~s}$. After $15 \mathrm{~min}$ of draining, $8 \mathrm{~kg}$ of apples was placed in a poplar crate, randomly, to reproduce "food-packaging" contacts in real conditions. Apples remained in contact with the wooden packaging for $5 \mathrm{~min}$. Then, they were carefully removed in order to have no impact on the apple contact mark. This labeling step was repeated on 3 different wooden crates in order to obtain an average contact area. Moreover, an isolated apple was stained as described above and put in contact with a poplar strip to define the area of a single contact point.

After drying for $24 \mathrm{~h}$, black and white pictures of marked packaging were taken using a CANON EOS 550D camera on a tripod. Pictures of labeled packaging were taken on a white background while those of the control packaging (unmarked) were taken on a black background. In both cases, the packaging was disassembled to obtain plane images and to quantify the contact surface area between the apples and the packaging.

The pictures were analyzed using the free ImageJ( $\odot$ software (http://imagej.nih.gov/ij/) to quantify the "apples-packaging" contact area. A double-decimeter was photographed in order to calibrate the images analyzed with Imagej@. A color threshold was applied to the pictures so that Imagej@ only took into account the black surfaces of the labeled packaging to quantify the real contact area. However, ImageJ@ took into account all the white surface of the control packaging to quantify the total internal surface area of a wooden crate.

\subsection{Microorganism strains and inoculum preparation}

E. coli strain (ATCC-700926) was stored in beads containing cryotubes at $-80^{\circ} \mathrm{C}$. To prepare the inoculum solution, two beads 
of a cryotube were suspended in $10 \mathrm{~mL}$ of PCA medium for $24 \mathrm{~h}$ at $37^{\circ} \mathrm{C}$ and $180 \mathrm{rpm} .1 \mathrm{~mL}$ of this sub-culture was then inoculated in $100 \mathrm{~mL}$ of PCA for $24 \mathrm{~h}$ at $37^{\circ} \mathrm{C}$ and $180 \mathrm{rpm}$. The concentration of this culture was measured by spectrophotometry (Spectronic ${ }^{\circledR} 20$ Genesys $^{\mathrm{TM}}$, Spectronic Instruments, United Kingdom) at $620 \mathrm{~nm}$ to standardize bacterial inoculum and was expected to be at $1 \times 10^{8} \mathrm{CFU} / \mathrm{mL}$. This solution was used to inoculate wood specimens and to prepare dilutions in sterile water with $0.9 \% \mathrm{NaCl}$. A concentration of the inoculum of $8 \times 10^{7}$ cells $/ \mathrm{mL}$ was chosen, according to Ismail et al. (2014).

P. expansum strain (ATCC-7861) was allowed to grow on malt/ agar medium (malt $40 \mathrm{~g} / \mathrm{L}$; agar $20 \mathrm{~g} / \mathrm{L}$ ). A spore suspension was generated by growing $P$. expansum on 4 malt/agar plates for 2 weeks at $22{ }^{\circ} \mathrm{C} .10 \mathrm{~mL}$ of water with $0.9 \% \mathrm{NaCl}$ and $0.05 \%$ Tween $^{\circledR}$ was added to each plate and spores were then collected in an Erlenmeyer flask containing beads. After filtration through sterile gauze, the spore suspension was rinsed three times in $10 \mathrm{~mL}$ of sterile water by centrifuging for $20 \mathrm{~min}$ at $2000 \mathrm{~g}$. Spores were then counted on a Malassez cell to prepare a suspension of $8 \times 10^{7}$ spores $/ \mathrm{mL}$. This was used to inoculate wood specimens after dilutions in sterile water with $0.9 \% \mathrm{NaCl}$. A concentration of the inoculum of $8 \times 10^{7}$ conidia/mL was chosen, according to Ismaïl et al. (2014).

\subsection{Moisture content of wood specimens}

A moisture content of $37 \%$ mass/mass was tested as this represents the usual "wet packaging" storage conditions. To obtain this moisture content, wood specimens were soaked in sterilized water for $1 \mathrm{~min}$ and weighed. They were then put in an oven at $103{ }^{\circ} \mathrm{C}$ for $48 \mathrm{~h}$ to determine their dry mass. The moisture content was then measured as described in Ismaiil et al. (2014) to ensure that wood specimens had a $37 \%$ moisture content.

An additional series of wood specimens was prepared with a moisture content of $18 \% \mathrm{~m} / \mathrm{m}$. This represents the usual "dry packaging" conditions of poplar crates. To obtain this moisture content, wood specimens were soaked in sterilized water for $30 \mathrm{~s}$ and weighed. They were then put in an oven at $103{ }^{\circ} \mathrm{C}$ for $48 \mathrm{~h}$ to determine their dry mass. The moisture content was then measured as described in Ismail et al. (2014) to ensure that wood specimens had $18 \%$ moisture content.

\subsection{Viability control of inocula}

A viability control was carried out to determine the concentration of viable microorganisms in tested solutions.

For $P$. expansum, inoculum viability was assessed by spreading $100 \mu \mathrm{L}$ of serial dilutions on malt/agar plates (malt $40 \mathrm{~g} / \mathrm{L}$; agar $20 \mathrm{~g} /$ L). After incubation for $48 \mathrm{~h}$ at $22{ }^{\circ} \mathrm{C}$, colonies were enumerated to determine the inoculum viability.

For E. coli, inoculum viability was assessed by putting $1 \mathrm{~mL}$ of serial dilutions on PCA plates. After incubation for $24 \mathrm{~h}$ at $37^{\circ} \mathrm{C}$, colonies were enumerated to determine the inoculum viability.

\subsection{Inoculation of wood specimens}

Sterile wood specimens of $60 \times 40 \mathrm{~mm}$, corresponding to a surface area of $24 \mathrm{~cm}^{2}$, were used. Each poplar specimen of $18 \%$ or $37 \%$ moisture content was inoculated in sterile conditions with $300 \mu \mathrm{L}$ of inocula. After $15 \mathrm{~min}$ of inoculum static impregnation, specimens were incubated alone or in contact with an apple for $1 \mathrm{~h}$ at room temperature, or 1 week at $10{ }^{\circ} \mathrm{C}$ and $85 \% \mathrm{RH}$. These conditions correspond to optimum storage conditions in a cold room (http://www.fruits-et-legumes.net/revue_en_ligne/point_ sur/fich_pdf/ECO/StockageFLEco.pdf). The wood specimens were grinded, as already described (Ismail et al., 2014) at different steps: immediately after $15 \mathrm{~min}$ of inoculum impregnation (T0), after $1 \mathrm{~h}$ of contact with an apple, after 1 week of contact with an apple.

\subsection{Inoculation of plates}

To ensure that apples did not affect the transfer of microorganisms, PCA plates and malt agar plates of $24 \mathrm{~cm}^{2}$ were inoculated in sterile conditions with $300 \mu \mathrm{L}$ of $E$. coli inoculum and $300 \mu \mathrm{L}$ of $P$. expansum inoculum, respectively. After $15 \mathrm{~min}$ of stabilization, each plate was incubated in contact with an apple. For P. expansum, incubation of 1 week at $10{ }^{\circ} \mathrm{C}$ and $85 \% \mathrm{RH}$ was carried out as it is representative of storage conditions in a cold room. For E. coli, incubation of $15 \mathrm{~min}$ at ambient temperature was carried out to avoid the development of $E$. coli on plates.

\subsection{Microbial analysis}

After incubation, microorganisms from wood specimens were recovered by grinding as already described in Ismaïl et al. (2014). The recovery solutions were inoculated by sowing $1 \mathrm{~mL}$ of serial dilutions on PCA (for E. coli) or $100 \mu \mathrm{L}$ of serial dilutions on malt/ agar (for $P$. expansum). After incubation at $22^{\circ} \mathrm{C}$ for $P$. expansum or $37^{\circ} \mathrm{C}$ for $E$. coli, colonies were enumerated.

After incubation, apples were peeled using a sterile stainless steel potato peeler to extract microorganisms. $5 \mathrm{~cm}^{2}$ of peel, corresponding to the contact surface area with wood specimens, was blended for 2 min using a Stomacher ${ }^{\circledR} 80$ (Seward, United Kingdom) in $6 \mathrm{~mL}$ of sterile water with $0.9 \% \mathrm{NaCl}$. Then suspensions were inoculated by sowing $1 \mathrm{~mL}$ of serial dilutions on PCA (for E. coli) or $100 \mu \mathrm{L}$ of serial dilutions on malt/agar (for P. expansum). After incubation at $22^{\circ} \mathrm{C}$ for P. expansum or $37^{\circ} \mathrm{C}$ for E. coli, colonies were enumerated.

\subsection{Statistical analysis}

The experiments described above were performed in triplicate. Results, expressed in $\mathrm{CFU} / \mathrm{cm}^{2}$ and transformed into $\log _{10}$ scale, correspond to the mean value \pm standard deviation. They were analyzed using the Student t-test $(\mathrm{p}<0.05)$ with Minitab ${ }^{\circledR}$ statistical software 16 (Minitab ${ }^{\circledR}$ Inc.). The transfer level (\%) was expressed as follows: (CFU/ $\mathrm{cm}^{2}$ recovered on apples after incubation $) \times 100 /\left(\mathrm{CFU} / \mathrm{cm}^{2}\right.$ inoculated on wood specimens at $\left.\mathrm{T} 0\right)$.

\section{Results}

\subsection{Microorganism recovery on poplar specimens}

To assess the viability of $E$. coli and $P$. expansum on wood, suspensions of $4.14 \log \mathrm{CFU} / \mathrm{cm}^{2}$ and $5.57 \log \mathrm{CFU} / \mathrm{cm}^{2}$, respectively, were inoculated on wood specimens at $37 \%$ moisture content. Microbial analyses were performed on wood specimens immediately after inoculation (T0), after $1 \mathrm{~h}$ of incubation at room temperature, or 1 week at $10{ }^{\circ} \mathrm{C}$ and $85 \%$ of relative humidity. The results are presented in Fig. 1. At T0, after the microbiological extraction from wood specimens, $3.95 \log _{10} \mathrm{CFU}$ of $E$. coli $/ \mathrm{cm}^{2}$ and $5.36 \log _{10} \mathrm{CFU}$ of $P$. expansum $/ \mathrm{cm}^{2}$ were recovered. In comparison with the amount of viable $E$. coli and $P$. expansum inocula, these results confirm the reliable recovery rates obtained with the chosen extraction method described by Ismail et al. (2014) with both gram-negative bacteria and fungal spores.

\subsection{Microorganism survival on poplar}

The results in Fig. 1 suggest that $P$. expansum conidia could 


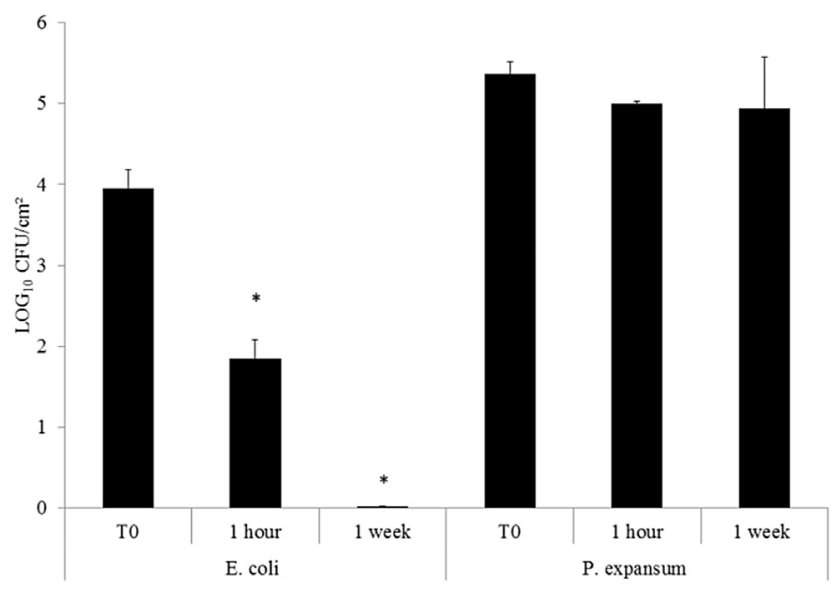

Fig. 1. Viability of E. coli or P. expansum on wood specimens after $1 \mathrm{~h}$ and 1 week of incubation. Enumeration corresponds to the mean value of 3 different apple surface enumerations $(\mathrm{n}=3)$. ${ }^{*}$ means significantly different from result obtained at T0 ( $\mathrm{p}<0.05$, Student t-test).

survive on wood specimens even after 1 week (at $10{ }^{\circ} \mathrm{C}$ and $85 \%$ of relative humidity), as between 4.94 and $5 \log _{10} \mathrm{CFU} / \mathrm{cm}^{2}$ were recovered whatever the incubation time. However, conidia of Penicillium expamsun did not grow. For E. coli, the results after $1 \mathrm{~h}$ and 1 week were significantly different from those obtained at T0. They suggest that $E$. coli could not survive on poplar under these conditions.

\subsection{Determination of the contact surface area between wooden crates and apples}

ImageJ@ software was used to quantify the total internal surface area of a poplar wooden crate used for apple storage: $3686.232 \mathrm{~cm}^{2}$. Fig. 2 represents the picture of the bottom of a poplar crate after contact with colored apples. All the "black surfaces" were analyzed by Imagej@ to calculate the real contact surface between the bottom of a poplar crate and apples. The average contact area (3 replicates) between a poplar wooden crate and $8 \mathrm{~kg}$ of Golden apples was $411.36 \mathrm{~cm}^{2} \pm 9.17$. Clearly, the repeatability of this test was not maximal ( $S D=9.17)$, due to the random disposition of apples in the wooden crates.

Image $\odot \odot$ software was used to quantify the area of a single point contact of Golden apples on poplar: $2.76 \mathrm{~cm}^{2}$. This represents only

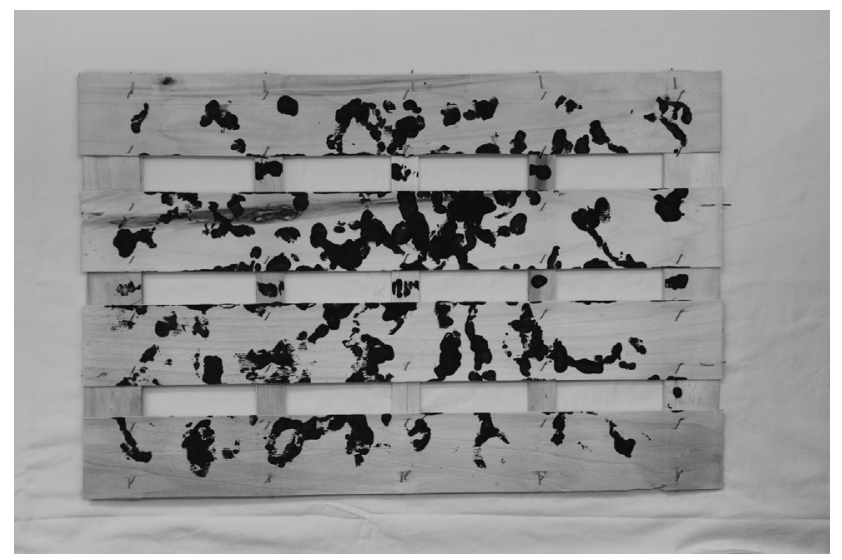

Fig. 2. Picture of the bottom of the poplar crate after contact with colored apples. Black surfaces represented the real contact surface between the bottom of the poplar crate and the apples in direct contact. This surface area was analyzed by ImageJ@.

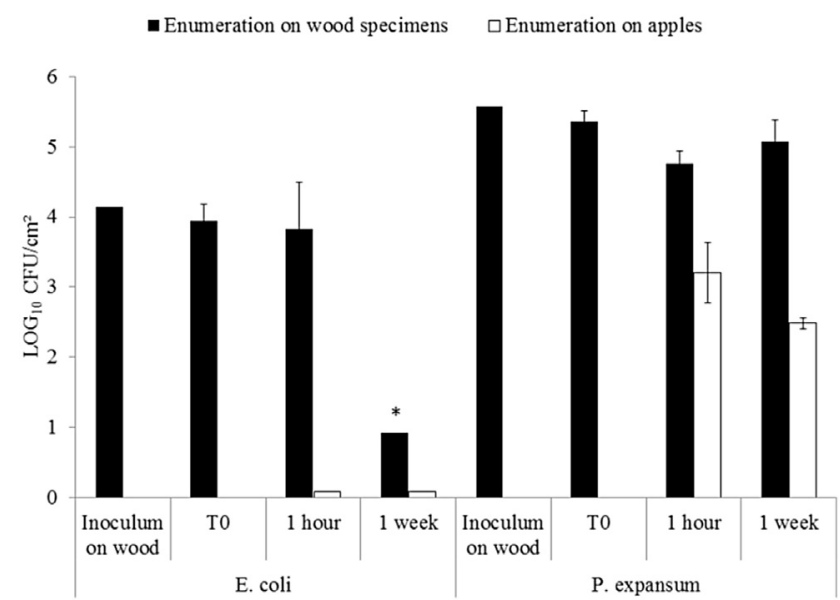

Fig. 3. Enumeration of E. coli or P. expansum on poplar specimens and apples after $1 \mathrm{~h}$ and 1 week. Enumeration corresponds to the mean value of 3 different wood specimen enumerations or of 3 different apple surface enumerations. * means significantly different from result obtained at T0 ( $\mathrm{p}<0.05$, Student t-test).

$1.51 \%$ of the total surface area of one apple.

So, in this study, we chose to consider that one contact point between an apple and wood had a surface area of $3 \mathrm{~cm}^{2}$ to facilitate the tests, and we chose to analyze $5 \mathrm{~cm}^{2}$ of apple peel to cover this contact area completely and to obtain robust results.

\subsection{Transfer of microorganisms from poplar specimens to apples}

To assess the transfer of $E$. coli and $P$. expansum from wood to apples, suspensions of $4.14 \log _{10} \mathrm{CFU} / \mathrm{cm}^{2}$ and $5.57 \log _{10} \mathrm{CFU} / \mathrm{cm}^{2}$, respectively, were inoculated in sterile conditions on wood specimens at $37 \%$ of moisture content. Apples were then put in contact with wood specimens. After incubation for $1 \mathrm{~h}$ at room temperature or 1 week at $10^{\circ} \mathrm{C}$ and $85 \% \mathrm{RH}$, microbial analyses were performed on wood specimens and on apples to assess the proportion of transfer. The results are presented in Fig. 3. Firstly, analyses of microorganisms on wood specimens in contact with apples were performed. For E. coli, the results after 1 week were significantly different from those obtained at T0. For P. expansum, from 4.76 to $5.36 \log _{10} \mathrm{CFU} / \mathrm{cm}^{2}$ were recovered on wood specimens, whatever the incubation time. These results, coupled with the data of Fig. 1, suggest that the recovery of these two microorganisms from wood specimens was not affected by contact with apples.

Then, analyses were performed on apples (Fig. 3). For E. coli, the recoveries were lower than the detection level of the method, suggesting that $E$. coli was not transferred from wood to apples. The corresponding transfer rates (see Table 3 ) after $1 \mathrm{~h}$ or 1 week, which were very low $(0.008 \%)$, confirmed this hypothesis. For P. expansum, $3.21 \log _{10} \mathrm{CFU} / \mathrm{cm}^{2}$ were recovered from apples after $1 \mathrm{~h}$ and 2.49 $\log _{10} \mathrm{CFU} / \mathrm{cm}^{2}$ after 1 week. More than $2 \log _{10} \mathrm{CFU} / \mathrm{cm}^{2}$ were lost between the recovery on wood at T0 and the recovery on apples after $1 \mathrm{~h}$ or 1 week. Corresponding transfer rates (Table 3) after $1 \mathrm{~h}$ or 1 week were between $0.08 \%$ and $0.25 \%$. These results demonstrate that $E$. coli did not seem to be transferred from wood to

Table 1

Control of transfer - Enumeration of E. coli or P. expansum on apples after incubation on inoculated agar plates. Enumeration corresponds to the mean value of 3 different apple surface enumerations.

\begin{tabular}{lll}
\hline Microorganism & E. coli & P. expansum \\
\hline Inoculum on agar plates $\log 10\left(\mathrm{CFU} / \mathrm{cm}^{2}\right)$ & 4.11 & 5.56 \\
Enumeration on apples $\log 10\left(\mathrm{CFU} / \mathrm{cm}^{2}\right)$ & $4.16 \pm 0.40$ & $5.30 \pm 0.62$ \\
\hline
\end{tabular}


Table 2

Enumeration (mean value \pm standard deviation) of $P$. expansum on wood specimens and on apples after 1 week of incubation according to the moisture content of wood. Enumeration corresponds to the mean value of 3 different apple surface enumerations or of 3 different wood specimen enumerations.

\begin{tabular}{lr}
\hline Moisture content of wood & $18 \%$ mass $/$ mass \\
\hline Enumeration on wood specimens without contact $\log _{10}\left(\mathrm{CFU} / \mathrm{cm}^{2}\right)$ & $5.49 \pm 0.04$ \\
Enumeration on wood specimens after contact with an apple $\log _{10}\left(\mathrm{CFU} / \mathrm{cm}^{2}\right)$ & $5.44 \pm 0.15$ \\
Enumeration on apples $\log _{10}\left(\mathrm{CFU} / \mathrm{cm}^{2}\right)$ & $3.07 \pm 0.65$ \\
\hline
\end{tabular}

apples while the transfer of $P$. expansum from poplar to apples was very low.

The results with contact plates applied to the tested Golden apples were negative, demonstrating that disinfection had been fully carried out (data not shown).

To ensure that apple peel does not affect the growth of $E$. coli or $P$. expansum and thus their transfer, control samples were carried out. Plates were inoculated with suspensions of microorganisms and put in contact with apples. After incubation, microbial analyses of apples were carried out (Table 1). For E. coli, $4.11 \log _{10} \mathrm{CFU} / \mathrm{cm}^{2}$ were inoculated and $4.16 \log _{10} \mathrm{CFU} / \mathrm{cm}^{2}$ were recovered on apples. For P. expansum, $5.56 \log _{10} \mathrm{CFU} / \mathrm{cm}^{2}$ were inoculated and 5.30 $\log _{10} \mathrm{CFU} / \mathrm{cm}^{2}$ were recovered on apples. These results demonstrate that when microorganisms were inoculated on PCA plates, the transfer to apples was not affected by the peel for both microorganism. Apples did not affect the observed transfer rates.

\subsection{Impact of contact duration between inoculated wood and apples on the transfer level}

Whatever the contact time considered ( $1 \mathrm{~h}$ or 1 week) between wood inoculated with $E$. coli and apples, the transfer rate was lower than $0.008 \%$ (Table 3 ).

The transfer of $P$. expansum from wood exposed to apples for $1 \mathrm{~h}$ was $0.25 \%$, whereas it was $0.08 \%$ from wood exposed to apples for 1 week.

\subsection{Impact of wood moisture content on the transfer rate}

Considering that only the transfer of $P$. expansum from wood specimens to apples was over the detection level, the influence of wood moisture content on transfer rate was assessed for this

Table 3

Transfer rates obtained from wood to apples, in the three separate experiments managed during this study.

\begin{tabular}{|c|c|c|c|}
\hline Experiment & $\begin{array}{l}\text { Condition (wood moisture } \\
\text { content - contact time) }\end{array}$ & Microorganism & $\begin{array}{l}\text { Transfer } \\
\text { rate (\%) }\end{array}$ \\
\hline \multirow{8}{*}{$\begin{array}{l}\text { Impact of microorganisms } \\
\text { and impact of contact } \\
\text { time between wood } \\
\text { and apple specimens }\end{array}$} & $37 \%$ & \multirow[t]{4}{*}{ E. coli } & \multirow[t]{2}{*}{$<0.008$} \\
\hline & $1 \mathrm{~h}$ & & \\
\hline & $37 \%$ & & \multirow[t]{2}{*}{$<0.008$} \\
\hline & 1 week & & \\
\hline & $37 \%$ & \multirow[t]{4}{*}{ P. expansum } & \multirow[t]{2}{*}{0.25} \\
\hline & $1 \mathrm{~h}$ & & \\
\hline & $37 \%$ & & \multirow[t]{2}{*}{0.08} \\
\hline & 1 week & & \\
\hline \multirow{4}{*}{$\begin{array}{l}\text { Impact of wood moisture } \\
\text { content }\end{array}$} & $18 \%$ & \multirow[t]{4}{*}{ P. expansum } & \multirow[t]{2}{*}{0.06} \\
\hline & 1 week & & \\
\hline & $37 \%$ & & \multirow[t]{2}{*}{0.05} \\
\hline & 1 week & & \\
\hline \multirow[t]{8}{*}{ Impact of apple batch } & $37 \%-1 \mathrm{~h}$ & \multirow[t]{8}{*}{ P. expansum } & \multirow[t]{2}{*}{0.07} \\
\hline & Batch 1 & & \\
\hline & $37 \%-1$ week & & \multirow[t]{2}{*}{0.05} \\
\hline & Batch 1 & & \\
\hline & $37 \%-1 \mathrm{~h}$ & & \multirow[t]{2}{*}{0.10} \\
\hline & Batch 2 & & \\
\hline & $37 \%-1$ week & & \multirow[t]{2}{*}{0.06} \\
\hline & Batch 2 & & \\
\hline
\end{tabular}

microorganism.

Two wood moisture contents were tested: $18 \% \mathrm{~m} / \mathrm{m}$, corresponding to dry packaging storage conditions and $37 \% \mathrm{~m} / \mathrm{m}$, corresponding to wet packaging storage conditions. $6.64 \log _{10}$ CFU of P. expansum $/ \mathrm{cm}^{2}$ were inoculated on wood specimens and apples were put in contact with them. After incubation for 1 week at $10^{\circ} \mathrm{C}$ and $85 \% \mathrm{RH}$, microbial analyses were performed on wood specimens and on apples (Table 2). Our results demonstrate that there was no significant difference $(\mathrm{p}<0.05)$ between recovery rates obtained on wood at two different moisture contents (from 4.94 to $5.49 \log _{10} \mathrm{CFU} / \mathrm{cm}^{2}$ ) nor on apples in contact with wood (from 2.49 to $3.07 \log _{10} \mathrm{CFU} / \mathrm{cm}^{2}$ ). Corresponding transfer rates from wood to apple (Table 3 ) were $0.06 \%$ and $0.05 \%$ for a wood moisture content of $18 \%$ and $37 \%$, respectively. This result demonstrates that wood moisture content did not influence the proportion of microorganism transferred from wood to apples.

\subsection{Impact of apple batch variability on the transfer rate}

To assess whether the variability of apples coming from different suppliers could impact the transfer of $P$. expansum from wood specimens to apples, two batches were tested. A suspension of $6.64 \mathrm{log} \mathrm{CFU} / \mathrm{cm}^{2}$ was inoculated on wood specimens at $37 \%$ of moisture content. Apples were then put in contact with them. After incubation for $1 \mathrm{~h}$ at room temperature or 1 week at $10^{\circ} \mathrm{C}$ and $85 \%$ $\mathrm{RH}$, microbial analyses were performed on wood specimens and on apples to assess the transfer rate (Fig. 4). The results obtained on wood were identical for both batches. On apples, between 3.25 and $3.46 \log _{10} \mathrm{CFU} / \mathrm{cm}^{2}$ were recovered for both batches. Corresponding transfer rates (Table 3 ) ranged from $0.05 \%$ to $0.10 \%$ after $1 \mathrm{~h}$ or 1 week of contact and demonstrated that apple batches did not influence significantly $(\mathrm{p}<0.05)$ the transfer of $P$. expansum from wood to apple peel.

Results with contact plates applied on the tested apples were negative, demonstrating that disinfection had been fully carried out

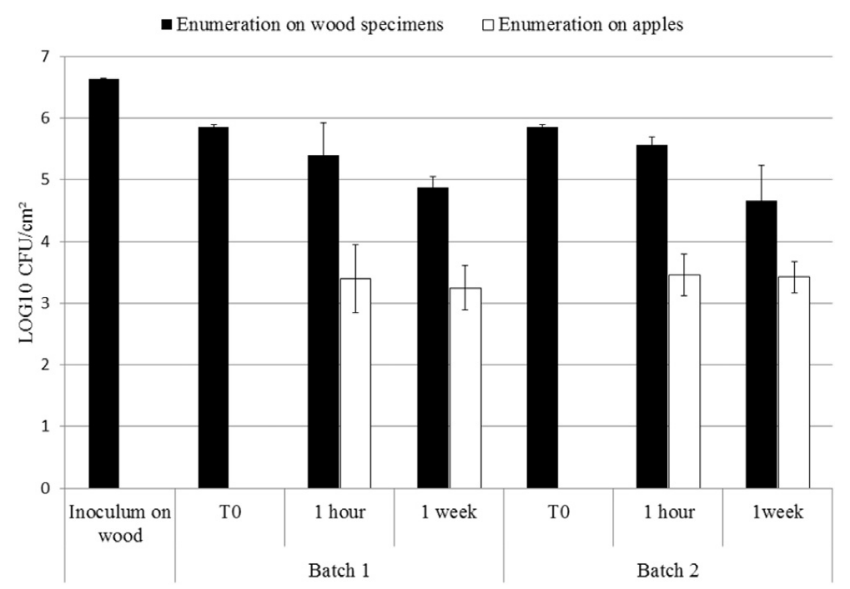

Fig. 4. Enumeration of $P$. expansum on wood specimens and two apple batches after $1 \mathrm{~h}$ and 1 week of incubation. Enumeration corresponds to the mean value of 6 different wood specimen enumerations from 2 experiments. 
(data not shown).

Taken together, the results from three separate series of 3 replicates (see Table 3) clearly demonstrate that the transfer of $P$. expansum from poplar specimens to apples did not exceed $0.25 \%$, regardless of the contact duration between wood and apples, the wood moisture content and the apple batch considered.

\section{Discussion}

In this study, E. coli and P. expansum behaved differently in terms of survival on poplar in the test conditions (Fig. 1). Once inoculated on poplar specimens and incubated at ambient temperature, viable E. coli cells decreased drastically after $1 \mathrm{~h}$ of contact. For $P$. expansum, conidia remained at $5 \log _{10} \mathrm{CFU} / \mathrm{cm}^{2}$ after $1 \mathrm{~h}$ and 1 week of contact. The hypothesis of bacteria entrapped in the wood matrix explaining the low recovery of E. coli is not valid. Indeed, the recovery methodology to extract microorganisms from wood led to $3.95 \log _{10} \mathrm{CFU} / \mathrm{cm}^{2}$ versus $4.14 \log _{10} \mathrm{CFU} / \mathrm{cm}^{2}$ inoculated.

However, the mortality of $E$. coli could be explained by the physiological differences between $E$. coli cells and $P$. expansum conidia. E. coli is a gram-negative bacterium whereas $P$. expansum conidia are resistant fungal cells. E. coli requires a temperature range of $7{ }^{\circ} \mathrm{C}-37^{\circ} \mathrm{C}$, a minimum water activity (aw) of 0.95 and a optimum pH of 6-7 (Foods, 1996; Presser, Ratkowsky, \& Ross, 1997). P. expansum is more tolerant to drastic conditions than E. coli as its conidia require a temperature range of $0{ }^{\circ} \mathrm{C}-35^{\circ} \mathrm{C}$, a minimum aw of 0.82 and a pH of 2-10 (ANSES, 2011; Pitt, Hocking, \& Diane, 2009). One hypothesis could be that poplar exhibits unfavorable conditions such as a low water activity and a $\mathrm{pH}$ of 5.8-6.4 (Balatinecz et al., 2014). It may be possible that, despite 37\% of moisture content, the local moisture on the wood surface was lower as wood is a material that dries easily. This could lead to a water activity lower than the one required for E. coli. Revol-Junelles, Miguindou-Mabiala, Roger-Maigné, and Millière (2005) found that the decrease in E. coli survival was probably linked to the desiccation of bacterial cells on poplar surfaces, because of its hygroscopic properties and natural wood extractives. Thus, poplar reduced E. coli survival when stored at ambient temperature or at $10{ }^{\circ} \mathrm{C}$ and 85\% RH (Revol-Junelles et al., 2005).

P. expansum conidia survival on poplar was constant whatever the incubation time. These results suggest that the conditions on poplar, such as surface moisture content and $\mathrm{pH}$, allowed P. expansum conidia to survive but not to grow (ANSES, 2011; Pitt et al., 2009).

Wood is a rough and porous material. Poplar, in particular, has numerous small pores, almost uniform and evenly distributed throughout a growth ring. Vessels have a diameter from 50 to $100 \mu \mathrm{m}$ (Jacquiot, Trenard, \& Dirol, 1973). Transfer and viability of E. coli from poplar to apple were lower than for $P$. expansum. This could be explained by the size of each microorganism. E. coli is a bacterium, measuring around $2 \mu \mathrm{m}$ (Zabel \& Morrell, 1992), whereas the conidia of $P$. expansum measure $3 \times 5 \mu \mathrm{m}$ and frequently aggregate to form chains (Larone, 2002). In this way, E. coli could penetrate more easily the first $2-3 \mathrm{~mm}$ of the wood surface and thus could be less easily transferred to apple. The penetration of bacteria was demonstrated by Mariani et al. in the case of L. monocytogenes within spruce boards (Mariani et al., 2011). Although spruce wood is different, the phenomenon exists.

Poplar also contains extractives such as tannins and quinones. These compounds can be found in wood, bark and leaves. They have antimicrobial action, related to their ability to inactivate microbial adhesins or enzymes, to transport proteins and to complex with polysaccharides and thus the microbial cell wall (Cowan, 1999). $E$. coli is a gram-negative bacterium, containing a thin peptidoglycan layer in its cell wall outside the cell membrane and also transport proteins called porins. Conidia of $P$. expansum possess a thick and tough cell wall. One hypothesis could be that these compounds complex with the cell wall of $E$. coli, leading to a lower viability for this bacterium than for conidia of $P$. expansum.

In this study, transfer rates obtained for $E$. coli and $P$. expansum from poplar to apples were very low, from $0.01 \%$ to $0.25 \%$ (from 2 to $4 \mathrm{log}$ of loss between wood and apple), after $1 \mathrm{~h}$ of incubation time. This result is fully in accordance with previous studies of transfer of microorganisms from wood to food. Transfer of $L$. monocytogenes from wooden cutting boards to chicken meat was strongly decreased, moving from $4.8 \log _{10} \mathrm{CFU} / \mathrm{mL}$ to $0.4 \log _{10} \mathrm{CFU} / \mathrm{mL}$ after $1 \mathrm{~h}$ of contact time (Goh et al., 2014). A study with several foodborne pathogens was performed to evaluate the transfer rate between stainless steel surfaces and foods. When the contamination level was moderate $\left(3 \log _{10} \mathrm{CFU} / \mathrm{cm}^{2}\right.$ ), the recovery of Salmonella enteritidis decreased below the detection limit $\left(4 \log _{10} \mathrm{CFU} / \mathrm{cm}^{2}\right.$ ) within $24 \mathrm{~h}$ (Kusumaningrum et al., 2003).

In this study, the microorganism transfer from poplar to apple occurred after one hour of contact (between inoculated wood and apple) and remained similar after one week of contact. This suggests a fast and passive transfer for both microorganisms tested in this study.

Differences in transfer rates could occur according to the quality of the foodstuffs considered, even if transfer rates are very low. Transfer rates of E. coli 0157:H7 strain to common kitchen surfaces were analyzed using celery, carrot, watermelon and lettuce. After $1 \mathrm{~h}$ of drying of the inoculated contact surfaces, freshly-cut celery, lettuce and carrots transferred more bacteria than watermelon (Jensen, Friedrich, Harris, Danyluk, \& Schaffner, 2013). The growth of this strain is dependent on the type of vegetable considered (Abadias, Alegre, Oliveira, Altisent, \& Viñas, 2012). In another study, the transfer of E. coli O157:H7 strain from stainless steel to several food products was, on the whole, higher for meat than for vegetables (Silagyi, Kim, Lo, \& Wei, 2009). The transmission of L. monocytogenes from a wooden board to chicken after 30 min was higher for cooled chicken meat (3.2 $\log \mathrm{CFU} / \mathrm{mL}$ ) than for hot chicken meat (0.8 log CFU/mL) (Goh et al., 2014).

Transfer rates of microorganisms could also be influenced by the properties of the "donor material" (poplar in our study) and the "receiver material" (apples in our study). Properties of materials such as surface characteristics and hydrophobicity could influence transfer rates. Wood is a rough and porous material and studies indicate that the greater the roughness is, the lower the transfer is (Midelet \& Carpentier, 2002; Pérez-Rodríguez, Valero, Carrasco, García, \& Zurera, 2008). The transfer of $L$. monocytogenes to beef was higher for biofilms formed on the polymers PU and PVC than for those formed on stainless steel (Midelet \& Carpentier, 2002). The recovery of Salmonella typhimurium after an absorption time of 10 min was lower on wood than on plastic (Gough \& Dodd, 1998). In a study dealing with adhesion and germination of $P$. expansum conidia on several surfaces, a link was established between wettability and attachment: the more the wettability increased, the more conidia adhesion decreased. Thus, attachment was higher on Teflon and polystyrene than on glass (Amiri et al., 2005). Topography and hydrophobic properties of surfaces seem to contribute greatly to transfer levels (Dawson, Han, Cox, Black, \& Simmons, 2007; Knobben, van der Mei, van Horn, \& Busscher, 2007).

One perspective could be to assess transfer rates of $E$. coli and $P$. expansum from wood to several foodstuffs and to compare transfer rates from several packaging materials to apples. In such a way, a link could be made between the transfer rates obtained and the surface properties of tested materials. Measurements of surface moisture content on wood could lead to a better understanding of E. coli mortality. In the meantime, the use of scanning electron microscopy could give added value by enabling the observation of 
bacteria cells and fungal conidia on wood specimens and other packaging materials.

\section{Conclusion}

This study proved that poplar used for crates leads to E. coli mortality within less than one week whereas it maintains the survival of $P$. expansum conidia without allowing its growth.

It also gives evidence that microorganisms, such as a gramnegative bacteria, a contaminant during food processing, and fungal spores, responsible for one of the major postharvest decay, do not transfer easily from wood to foodstuffs.

For both E. coli and P. expansum, and despite a high artificial contamination of poplar, the transfer rate from poplar to apples did not exceed $0.25 \%$, regardless of the wood moisture content, the contact time between inoculated wood and apples, and the apple supply origin.

This low transfer rate is linked to the poplar material and reinforces the good suitability of wood for contact with foodstuffs.

\section{Acknowledgments}

We thank Adeline Jasick and Martine Gabille (FCBA, Bordeaux, France) for their valuable technical assistance. We thank Sylvie Chevallier (GEPEA, Oniris, France) for technical support when using the ImageJ@ software. This research was financially supported by the French Scientific Consortium EMABOIS, the French Packaging Pole, the French Institution France Bois Forêt and the French Ministry of Agriculture, Food and Forestry.

\section{References}

1935/2004, R. E. (2004). In E. P. a. t. council (Ed.), REGULATION (EC) no 1935/2004 of the European Parliament and of the Council of 27 October 2004 on materials and articles intended to come into contact with food and repealing directives 80/590/ EEC and 89/109/EEC (Vol. EC 1935/2004, pp. 1-14). Official Journal of the European Union.

Abadias, M., Alegre, I., Oliveira, M., Altisent, R., \& Viñas, I. (2012). Growth potential of Escherichia coli 0157: H7 on fresh-cut fruits (melon and pineapple) and vegetables (carrot and escarole) stored under different conditions. Food Control, 27(1), 37-44.

Alegre, I., Abadias, M., Anguera, M., Usall, J., \& Viñas, I. (2010). Fate of Escherichia coli 0157: H7, Salmonella and Listeria innocua on minimally-processed peaches under different storage conditions. Food Microbiology, 27(7), 862-868.

Amiri, A., Cholodowski, D., \& Bompeix, G. (2005). Adhesion and germination of waterborne and airborne conidia of Penicillium expansum to apple and inert surfaces. Physiological and Molecular Plant Pathology, 67(1), 40-48.

Anonymous. (1945). Arrêté du 15 Novembre 1945 fixant la liste des matériaux susceptibles d'être utilisés sans inconvénient pour la santé publique dans la fabrication des instruments de mesures. France: Journal officiel, 29-31.

Anonymous. (2012). In DGCCRF (Ed.), 2012-93 Information note of the DGCCRF "Materials in contact with foodstuffs - case of wood" (Vol. 2012-93). France: DGCCRF.

ANSES. (2011). Penicillium expansum et autres moisissures productrices de patuline. Agence Nationale Securité sanitaire alimentation Environnement travail.

Balatinecz, J., Mertens, P., Boever, L. d., Yukun, H., JuWan, J., Acker, J. V., et al. (2014). Properties, processing and utilization. In Poplars and willows: Trees for society and the environment (pp. 527-561).

Buchanan, R., Edelson, S., Miller, R., \& Sapers, G. (1999). Contamination of intact apples after immersion in an aqueous environment containing Escherichia coli 0157: H7. Journal of Food Protection ${ }^{\circledR}, 62(5), 444-450$.

Callejón, R. M., Torijab, M. J., Masb, A., Moralesa, M. L., \& Troncosoa, A. M. (2010) Changes of volatile compounds in wine vinegars during their elaboration in barrels made from different woods. Food Chemistry, 120(2), 561-571.

Cao, B., Li, H., Tian, S., \& Qin, G. (2012). Boron improves the biocontrol activity of Cryptococcus laurentii against Penicillium expansum in jujube fruit. Postharvest Biology and Technology, 68, 16-21.

Chatterton, S., Wylie, A. C., \& Punja, Z. K. (2012). Fruit infection and postharvest decay of greenhouse tomatoes caused by Penicillium species in British Columbia. Canadian Journal of Plant Pathology, 34(4), 524-535.

Conway, W. S., Leverentz, B., Janisiewicz, W. J., Blodgett, A. B., Saftner, R. A., \& Camp, M. J. (2004). Integrating heat treatment, biocontrol and sodium bicarbonate to reduce postharvest decay of apple caused by Colletotrichum acutatum and Penicillium expansum. Postharvest Biology and Technology, 34(1), 11-20.
Reviews, 12(4), 564-582.

Dawson, P., Han, L., Cox, M., Black, C., \& Simmons, L. (2007). Residence time and food contact time effects on transfer of Salmonella Typhimurium from tile, wood and carpet: testing the five-second rule. Journal of Applied Bacteriology, 102, 945-953.

Dingman, D. W. (2000). Growth of Escherichia coli 0157:H7 in Bruised Apple (Malus domestica) tissue as influenced by cultivar, date of Harvest, and source. Applied and Environmental Microbiology, 66(3), 1077-1083.

Filip, S., Fink, R., Oder, M., \& Jevšnik, M. (2012). Hygienic acceptance of wood in food industry. Wood Science and Technology, 46(4), 657-665.

Foods, T. I. C. o. M. S. f (1996). Intestinally pathogenic Escherichia coli. In Micro-organisms in foods 5 microbiological specifications of food pathogens.

Goh, S. G., Leili, A.-H., Kuan, C. H., Loo, Y. Y., Lye, Y. L., Chang, W. S., et al. (2014). Transmission of Listeria monocytogenes from raw chicken meat to cooked chicken meat through cutting boards. Food Control, 37(0), 51-55.

Gougeon, R. D., Lucio, M., Frommberger, M., Peyron, D., Chassagne, D., Alexandre, H. et al. (2009). The chemodiversity of wines can reveal a metabologeography expression of cooperage oak wood. Proceedings of the National Academy of Sciences, 106(23), 9174-9179.

Gough, N. L. \& Dodd, C. E. R. (1998). The survival and disinfection of Salmonella typhimurium on chopping board surfaces of wood and plastic. Food Control, 9(6), 363-368.

Ikeura, H., Somsak, N., Kobayashi, F., Kanlayanarat, S., \& Hayata, Y. (2011). Application of selected plant extracts to inhibit growth of Penicillium expansum on apple fruits. Plant Pathology Journal, 10(2).

Ismaïl, R., Le Bayon, I., Michel, V., Jequel, M., Kutnik, M., Aviat, F., et al. (2014). Comparative study of three methods for recovering microorganisms from wooden surfaces in the food Industry. Food Analytical Methods, 1-10.

Jacquiot, C., Trenard, Y., \& Dirol, D. (1973). Atlas d'anatomie des bois des angiospermes (essences feuillues), 2 vols (Vol. 72): Paris.

Janisiewicz, W., Conway, W., \& Leverentz, B. (1999). Biological control of postharvest decays of apple can prevent growth of Escherichia coli 0157: H7 in apple wounds. Journal of Food Protection ${ }^{\circledR}$, 62(12), 1372-1375.

Jensen, D. A. Friedrich, L. M., Harris, L. J. Danyluk, M. D. \& Schaffner, D. W. (2013). Quantifying transfer rates of Salmonella and Escherichia coli 0157:H7 between fresh-cut produce and common kitchen surfaces. Journal of Food Protection, 76(9), 1530-1538.

Knobben, B. A., van der Mei, H. C., van Horn, J. R., \& Busscher, H. J. (2007). Transfer of bacteria between biomaterials surfaces in the operating room-an experimental study. Journal of Biomedical Materials Research Part A, 80(4), 790-799.

Kusumaningrum, H. D. Riboldi, G. Hazeleger W. C, \& Beumer, R. R. (2003). Survival of foodborne pathogens on stainless steel surfaces and cross-contamination to foods. International Journal of Food Microbiology, 85(3), 227-236.

Larone, D. (2002). Medically important Fungi 4th. Washington, DC: American Society for Microbiology.

Leverentz, B., Conway, W. S., Janisiewicz, W., \& Camp, M. J. (2004). Optimizing concentration and timing of a phage spray application to reduce Listeria monocytogenes on Honeydew melon tissue. Journal of Food Protection, 67(8), $1682-1686$

Liu, H., Jiang, W., Bi, Y., \& Luo, Y. (2005). Postharvest BTH treatment induces resistance of peach (Prunus persica L. CV. Jiubao) fruit to infection by Penicillium expansum and enhances activity of fruit defense mechanisms. Postharvest Biology and Technology, 35(3), 263-269.

Mariani, C., Oulahal, N., Chamba, J. F., Dubois-Brissonnet, F., Notz, E., \& Briandet, R. (2011). Inhibition of Listeria monocytogenes by resident biofilms present on wooden shelves used for cheese ripening. Food Control, 22(8), 1357-1362.

Midelet, G., \& Carpentier, B. (2002). Transfer of microorganisms, including Listeria monocytogenes, from various materials to beef. Applied and Environmental Microbiology, 68(8), 4015-4024.

Palou, L., Montesinos-Herrero, C., Taberner, V., \& Vilella-Esplá, J. (2013). First report of Penicillium expansum causing Postharvest Blue mold of fresh date Palm fruit (Phoenix dactylifera) in Spain. Plant Disease, 97(6), 846-846.

Pérez-Rodríguez, F., Valero, A., Carrasco, E., García, R. M., \& Zurera, G. (2008). Understanding and modelling bacterial transfer to foods: a review. Trends in Food Science \& Technology, 19(3), 131-144.

Pitt, J. I., Hocking, A. D., \& Diane, A. (2009). Fungi and food spoilage (Vol. 519). Springer.

Presser, K., Ratkowsky, D., \& Ross, T. (1997). Modelling the growth rate of Escherichia coli as a function of $\mathrm{pH}$ and lactic acid concentration. Applied and Environmental Microbiology, 63(6), 2355-2360.

Pui, C., Wong, W., Chai, L., Lee, H., Tang, J. Y. H., Ahmad, N., et al. (2011). Biofilm formation by Salmonella Typhi and Salmonella Typhimurium on plastic cutting board and its transfer to dragon fruit. International Food Research Journal, 18(1), $31-38$.

Revol-Junelles, A.-M., Miguindou-Mabiala, R., Roger-Maigné, D., \& Millière, J.-B. (2005). Behavior of Escherichia coli cells and Bacillus cereus spores on poplar wood crates by impedance measurements. Journal of Food Protection, 68(1), 80-84.

Richard, J. (1997). Utilisation du bois comme matériau au contact des produits laitiers. Comptes Rendus de l'Academie d'Agriculture de France, 83(5), 27-34.

Sanborn, L. W. R. (1963). The relation of surface contamination to the transmission of disease. American Journal of Public Health and the Nations Health, 53(8), $1278-1283$.

Sanderson, P., \& Spotts, R. (1995). Postharvest decay of winter pear and apple fruit caused by species of Penicillium. Phytopathology, 85(1), 103-110. 
Silagyi, K., Kim, S.-H., Lo, Y. M., \& Wei, C.-i (2009). Production of biofilm and quorum sensing by Escherichia coli 0157: H7 and its transfer from contact surfaces to meat, poultry, ready-to-eat deli, and produce products. Food Microbiology, 26(5), 514-519.

Sivapalasingam, S., Friedman, C. R., Cohen, L., \& Tauxe, R. V. (2004). Fresh produce: a growing cause of outbreaks of foodborne illness in the United States, 1973 through 1997. Journal of Food Protection, 67(10), 2342-2353.

Vojdani, J. D., Beuchat, L. R., \& Tauxe, R. V. (2008). Juice-associated outbreaks of human illness in the United States, 1995 through 2005. Journal of Food Protection, 71(2), 356-364.

Wang, L., Jin, P., Wang, J., Jiang, L., Zhang, S., Gong, H., et al. (2015). In vitro inhibition and in vivo induction of defense response against Penicillium expansum in sweet cherry fruit by postharvest applications of Bacillus cereus AR156. Postharvest Biology and Technology, 101, 15-17.

Wang, L., Wu, H., Qin, G., \& Meng, X. (2014). Chitosan disrupts Penicillium expansum and controls postharvest blue mold of jujube fruit. Food Control, 41, 56-62.
Wilks, S., Michels, H., \& Keevil, C. (2005). The survival of Escherichia coli 0157 on a range of metal surfaces. International Journal of Food Microbiology, 105 445-454.

Wilks, S. A., Michels, H. T., \& Keevil, C. W. (2006). Survival of Listeria monocytogenes Scott A on metal surfaces: implications for cross-contamination. International Journal of Food Microbiology, 111(2), 93-98.

Xiao, C., Kim, Y., \& Boal, R. (2014). First report of occurrence of pyrimethanil resistance in Penicillium expansum from stored apples in Washington State. Plant Disease, 98(7), 924-928.

Yu, Q., Chen, Q., Chen, Z., Xu, H., Fu, M., Li, S., et al. (2012). Activating defense responses and reducing postharvest blue mold decay caused by Penicillium expansum in peach fruit by yeast saccharide. Postharvest Biology and Technology, $74,100-107$.

Zabel, R., \& Morrell, J. (1992). Wood microbiology: Decay and its preservation. San Diego: Academic Press. 